\title{
Smart I'rab: Smart Aplicasion for Arabic Grammar Learning
}

\author{
Syd. Ali Zein Farmadi, Ali Ridho Barakbah, \\ Entin Martiana Kusumaningtyas \\ Department of Information and Computer Engineering \\ Electronic Engineering Polytechnic Institute of Surabaya \\ Email: farmady@student.eepis-its.edu,ridho@eepis-its.edu,entin@eepis-its.edu
}

\begin{abstract}
Arabic grammar, known as nahwu, is necessary to comprehend the Holy Qur'an that is completely written in Arabic. However, many people get trouble to study this skill because there are various kinds of word formation and sentences that may be created from a single verb, noun, adjective, subject, predicate, object, adverb or another formation. This research proposes a new approach to identify the position and word function in Arabic sentence. The approach creates smart process that employs Natural Language Processing (NLP) and expert system with modeling based on knowledge and inference engine in determining the word position. The knowledge base determines the part of speech while the inference engine shows the word function in the sentence. On processing, the system uses 82 templates consisting of 34 verb templates, 34 subject pronouns, 14 pronouns for object or possessive word. All the templates are in the form of char array for harakat (vowel) and letters which become the comparators for determining the part of speech from input word sentence. Output from the system is an i'rab (the explanation of word function in sentence) written in Arabic. The system has been tested for 159 times to examine word and sentence. The examination for word that is done 117 times has not made any error except for the word that is really like another word. While the detection for word function in sentence that is done 42 times experiment, there is no error too. An error happens when the part of speech from the word being examined is not included in the system yet, influencing the following word function detection.
\end{abstract}

Keywords: I'rab, Arabic grammar, NLP, expert system, knowledge base, inference engine.

\section{INTRODUCTION}

Nowdays, there are many students from religious high school and houses of Koranic studies who want to study Islam. One of the skills is nahwu, the principles of arabic language. Nahwu studies about word function 
in a sentence. Nahwu makes the arabic translation easier to understand the meaning and to avoid misinterpretion on the bias meaning. Principelly, nahwu is used to comprehend the holy qur'an of musleem book that is written in arabic. Nahwu has a branch of knowledge called as i'rab meaning the transformation of suffix to give a word distinctive use in sentence such as lafdhz, (spoken word) and taqdir, (predicted word) [4]. So the i'rab can show the function word in sentence which gives readers clear explanation for easy understanding.

\section{RELATED WORKS}

There were some researchers such as Harmain, El-Khatib dan Lakas[1]who have made softwares about arabic language. They use NLP (Natural Language Processing) modul and database access to determine the part of speech. Besides, El-Kourdi et all [2]made a system by using algoritm Naive Bayes to clarify an arabic document . Furthermore, El Halees [3] used a method with an association rule to clarify arabic language document. But, these studies do not highlight the arabic grammar.

\section{ORIGINALITY}

This research proposes a new approach for identifying the position and part of speech in arabic sentence by developing smart process involving NLP (Natural Language Processing) and expert system with a modelling on knowledge base and inference engine to determine the part of speech. The knowlelge base together with char array and string database creates the part of speech, while the inference engine shows the word function in sentence.

\section{SYSTEM DESIGN}

Arabic grammar has several branches of knowledge. One of them is nahwu that is useful to determine the word function in an arabic sentence. The nahwu itself has another branch that is called as i'rab. I'rab means to change the suffic of word to distinct the use in sentence. Two of the i'rab are lafdhz (spoken word) and taqdir (predicted word) [4].

This research proposes a new approach to identify the types and parts of speech in the sentence in arabic language by developing smart process that involves NLP (Natural Language Processing), and expert system with modelling based on knowledge base and inference engine. The knowledge base creates the types of word, while inference engine creates the function word in the sentence.

NLP is used to form an expert system., the branches of NLP that are applied in this research are morphology and syntaxes. Morphology is the knowledge about word and word formation. The morphology gives clear distinction among the derivatives [5]. Syntaxes are knowledge about the way how arrange words in making sentences [5]. In this research, morphology is used to form knowledge base for detecting a word. However, the syntaxes are used by the inference engine to detect a sentence. 
Meanwhile the expert system is a tool with software developed to provide flexible system for knowledge designer to solve specific problems [6].

This research proposes a smart process involving both Knowledge Base and Inference Engine. The knowledge base consists of templates functioning as comparators for all kinds of word. Does the word belong to fi'il (verb), dhomir (pronoun), dhzaraf (adverb) or adawat (word that changes the part of speech). The Inference Engine contains the process for detecting part of speech which is then determined to find out the function of the word in a sentence. The Architecture System proposed can be seen on Figure 1.

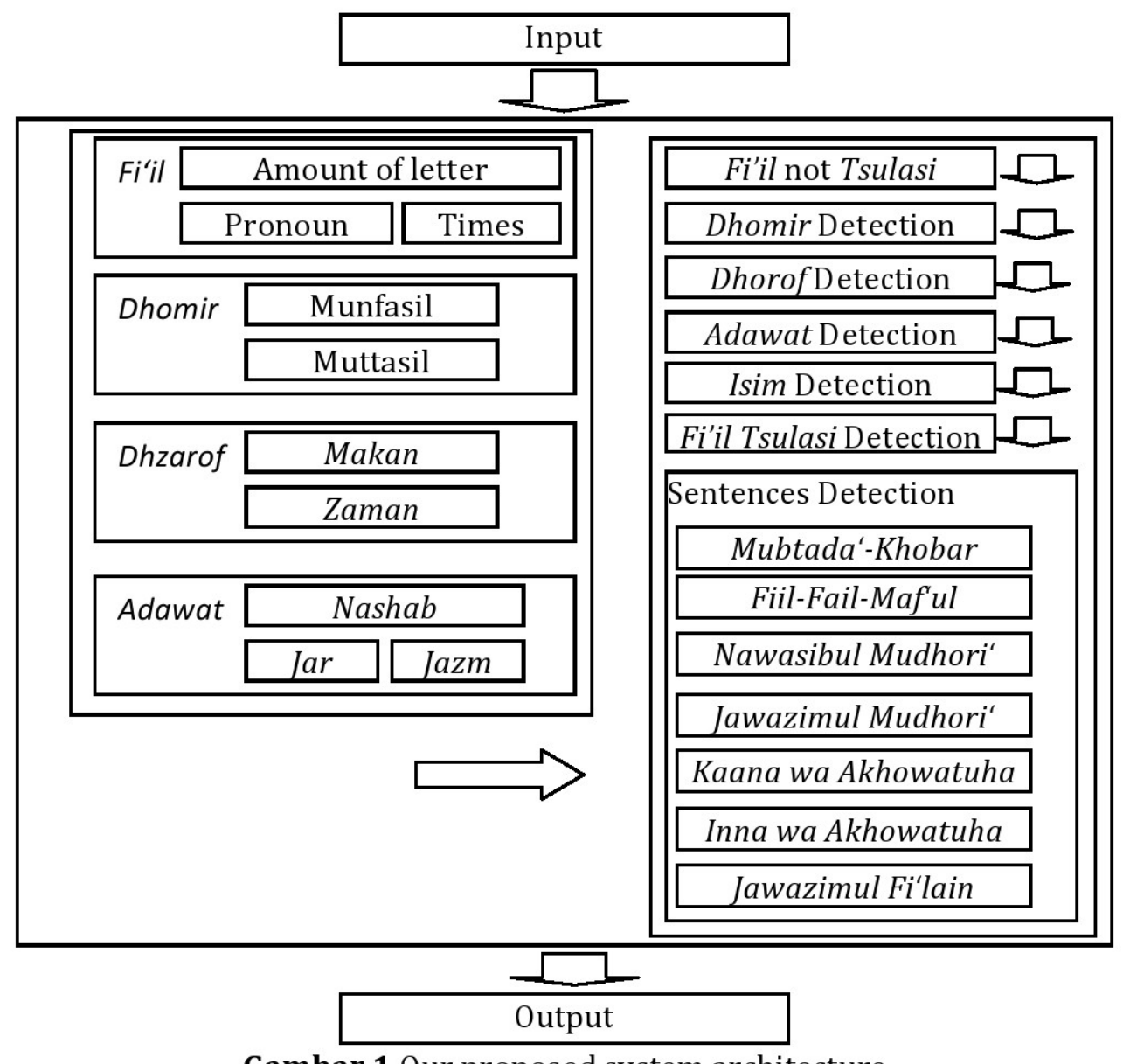

Gambar 1.0ur proposed system architecture

\subsection{Knowledge Base}

In this research, facts are classified into four kinds of word, namely fi'il, dhomir, dhzaraf, and adawat.

\subsection{1 فعل(Fi'il) means verb.}

The verb is limited only tofi'il shahih that is classified into three parts:

1. The time when an event happens is classified into:

a. ماض (Madhi): past. 
b. مضارع (Mudhori'): now and future.

c. امر (Amr): imperative.

2. There are many letters that can change word into verb which then becomes wazan (norm). These norms are:

a. ثلاثي (Tsulatsi): a word consisting of three letters and the pattern only uses vowel /a/. In this study the three types of wazan tsulatsi are introduced.

b. رباعي (Ruba'i):a word consisting four letters including the addition of vowel /i/ and another letter. In this study the three types of wazan ruba'I are introduced.

c. خماسي (Khumasi): a word consisting of five letters. In this study the five types of wazan khumasi are introduced.

d. سداسي (Sudasi):a word consisting of six letters. In this study the six types of wazan sudasi are introduced.

3. The pronoun of subject is implied in it.

The templatefor verb devision can be seen on Table 1 and Table 2 .

Tabel 1.Template of letter for fi'il madhi

\begin{tabular}{|l|c|c|c|c|c|}
\hline \multicolumn{1}{|c|}{ Wazan } & \multicolumn{6}{c|}{ Huruf } \\
\hline Fa'ala & 0 & 1 & 2 & 3 & 4 \\
\hline Fa'ila & & & & & \\
\hline Fa'ula & & & & & \\
\hline Fa'ala (withtasydid) & & & & & \\
\hline Af'ala & & & & & \\
\hline Faa'ala & 1 & & & & \\
\hline If'alla & & 1 & & & \\
\hline Infa'ala & 1 & & & & \\
\hline Ifta'ala & 1 & $ن$ & & & \\
\hline Tafa'ala & 1 & & $ت$ & & \\
\hline Tafaa'ala & $ت$ & & & & \\
\hline Istaf'ala & $ت$ & & 1 & & \\
\hline
\end{tabular}

Tabel 2.Template harakatforfi'il madhi

\begin{tabular}{|c|c|c|c|c|c|}
\hline Wazan & \multicolumn{5}{|c|}{ Harakat } \\
\hline & 0 & 1 & 2 & 3 & 4 \\
\hline Fa'ala & 8 & 8 & 6 & & \\
\hline Fa'ila & 8 & 9 & 6 & & \\
\hline Fa'ula & 8 & 8 & 6 & & \\
\hline Fa'ala (dengan tasydid) & 6 & 8 & 6 & & \\
\hline Af'ala & क & $\dot{8}$ & 8 & & \\
\hline Faa'ala & क & 8 & & & \\
\hline If'alla & , & 8 & 6 & 8 & \\
\hline Infa'ala & 9 & $\dot{8}$ & 5 & 6 & \\
\hline Ifta'ala & 8 & $\dot{0}$ & 5 & 5 & \\
\hline Tafa'ala & b & 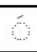 & 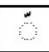 & 8 & \\
\hline Tafaa'ala & 8 & 5 & 6 & & \\
\hline Istaf'ala & 8 & $\dot{0}$ & 5 & $\dot{8}$ & 8 \\
\hline
\end{tabular}


4.1.2 ضمير (Dhomir)means the pronoun for (first, second, and third person), in whichit implies:

1. Munfashil(pronoun that can stand alone without being linked to the following word).DhomirMunfashil can easily be recognized by the string of letters.

2. Muttashil (that is linked to the following word). This includes:

a. When the pronoun position is before fi'il, it becomes the pronoun of the object.

b. When the pronoun position is before isim (noun), it becomes possessive pronoun.

The template for dhomir muttashil can be seen on Table 3.

Tabel 3. Template of dhomir muttashil

\begin{tabular}{|c|c|c|c|c|c|c|c|c|c|c|}
\hline \multirow{2}{*}{ JenisDhomir } & \multicolumn{5}{|c|}{ Huruf (Length - x) } & \multicolumn{5}{|c|}{ Harakat (Length - x) } \\
\hline & $\mathrm{L}-1$ & $\mathrm{~L}-2$ & $\mathrm{~L}-3$ & $\mathrm{~L}-4$ & $\mathrm{~L}-5$ & $\mathrm{~L}-1$ & $\mathrm{~L}-2$ & L-3 & $\mathrm{L}-4$ & $\mathrm{~L}-5$ \\
\hline Huwa 1 & $\circ$ & & & & & 8 & & & & \\
\hline Huwa 2 & 0 & & & & & 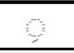 & & & & \\
\hline Humaa (L) 1 & 1 & 3 & 0 & & & 8 & 8 & & & \\
\hline Humaa (L) 2 & 1 & 5 & 0 & & & 8 & 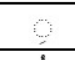 & & & \\
\hline Hum 1 & 5 & 0 & & & & $\dot{8}$ & 8 & & & \\
\hline Hum 2 & r & 0 & & & & i & 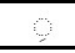 & & & \\
\hline Hiya & 1 & - & & & & 8 & - & & & \\
\hline Humaa (P) 1 & 1 & 5 & 0 & & & 8 & 8 & & & \\
\hline Humaa (P) 2 & 1 & b & 0 & & & 8 & 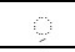 & & & \\
\hline Hunna 1 & ن & 0 & & & & 8 & 8 & $\dot{8}$ & & \\
\hline Hunna 2 & $\dot{ن}$ & 0 & & & & 8 & 8 & 8 & & \\
\hline Anta & ك & & & & & 8 & 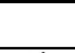 & & & \\
\hline Antumaa (L) & 1 & 5 & ك & & & 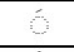 & $\dot{8}$ & & & \\
\hline Antum & r & ك & & & & $\dot{8}$ & 8 & & & \\
\hline Anti & ك & & & & & 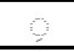 & 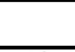 & & & \\
\hline Antumaa (P) & 1 & 5 & ك & & & 8 & 8 & & & \\
\hline Antunna & $\dot{~ ن}$ & ك & & & & 8 & 8 & 8 & & \\
\hline Ana 1 & ي & & & & & $\dot{0}$ & & & & \\
\hline Ana 2 & ي & $\dot{ن}$ & & & & $\dot{0}$ & ? & & & \\
\hline Ana 3 & ي & & & & & 8 & $\dot{8}$ & & & \\
\hline Nahnu & 1 & $\dot{ }$ & & & & 8 & & & & \\
\hline
\end{tabular}

4.1.3 ظرف (Dhzaraf) has functions that determine the time and place of which it implies:

1. DhzarafMakan (determining the place)

2. DhzarafZaman (determining the time)

4.1.4 ادوات Adawathas functions to change the position in a sentence. The functions are limited to the instrument that can stand alone (separated by space). The adawat contains: 
1. Nashab (the instrument that changes the part of speech into word ending with fathah)

2. Jar (the instrument that changes the part of speech into word ending with kasrah)

3. Jazm (the instrument that changes the part of speech into word ending with sukun)

\subsection{Inference Engine}

Executes the detection of word function according to the following chronological steps:

1. Detection is intended to verb that is nottsulatsi (includingruba'i, khumasi, orsudasi detected from its pattern).

2. Detection fordhomir (pattern detection).

3. Detection fordhzaraf (string databasedetection).

4. Detection for adawat (string databaseand pattern detection).

5. Detection forisim.

6. Detection fora verbtsulatsi.

7. Detection for syntax. In this research, the detection is intended to the formation of 7 types of sentence in Arabic language, that is:

a. Mubtada'-Khabar. It is concluded when a sentence is begun with isimof which the isimhas dhommahordhommatainasending harakat, the word becomes mubtada'. Then, when the mubtada'is followed by another isimhaving ending dhommahordhommatainas final harakat, the word becomeskhabarmubtada'.

b. Fi'il-Fa'il-Maf'ul. It is concluded when a sentence is begun with fi'il, and followed by isim with finalharakat indhommahordhommatainthat becomes fa'il (subyect), then followed by isimhaving final harakatfathahorfathatainbecoming maf'ul bih (object).

c. Nawaashibul Mudhori'. It is concluded when a sentence is begun with adawatnashab, the sentence is followed byfi'il mudhori'having ending sound vowel /a/,fathah.

d. Jawaazimul Mudhori'. It is concluded when a sentence is begun with adawat jazm, the sentence is followed by fi'il mudhori'having ending sound vowel /u/,sukun.

e. Kaana wa Akhawatuha. It is concluded when a sentence is begun with the wordkaanaor word having function as relatives of kana, the word is followed by isim having ending sound as vowel $/ \mathrm{u} /$, dhommah atau dhommatain, called as isim kaana which is then followed by another word having ending sound vowel /a/, fathah or fathatain later called as khabar kaana.

f. Inna wa Akhawatuha. It is concluded when a sentence begins with word inna or word having function as inna relatives, the word is followed by isim having ending sound vowel /a/, fathah or fathatain later called as isiminna, then it is followed by word having ending 
sound /u/, dhommahordhommatain which is then called as khabar inna.

g. Jawaazimul Fi'lain. It is concluded when a sentence is begun with adawatjazm, the word will be followed by fi'il mudhori'having ending sound as vowel /u/ sukun. It is then followed by the fi'il mudhori'of which it has similar ending sound as sukun.

\section{EXPERIMENTS AND ANALYSIS}

The research has already done159 experiments consisting of 117 times for words and 42 for sentences.

\subsection{Experiment for words}

The word experiment is divided into 26 experiments for fi'ilmadhi (12 wazan, 14 dhomir), 26 experiments for fi'ilmudhori' (12 wazan, 14 dhomir, 17 experiments for fi'il 'amr (11 wazan, 6 dhomir), 14 experiment for dhomirmusfashil, 28 experiments for dhomirmuttashil (14 for pronouns of object, 14 for possessive pronouns), 2 experiments for dhzaraf (eating and period), 3 experiments for harf (hasb, jar, jazm) and 1 experiment for isim (noun). However, the error of experiment refers to the following:

1.The subject pronoun for fi'ilmadhi and fi'il 'amr, dhomirantumamuannats has the same form with dhomirantumamudzakkar.

2. The subject pronoun for fi'ilmudhori' has made two errors such as:

a. Dhomir anta has similar form to dhomir hiya.

b. Dhomir antuma mudzakkar dan dhomir antuma muannats has similar form to dhomir huma muannats.

3. The dhomir muttashil dan dhomir munfashilhas made two errors such as:

a. Dhomirhumamuannats has similar form to dhomir hum mudzakkar.

b. Dhomirantumamuannats has similar form to dhomirantumamudzakkar.

\subsection{Experiment for sentences}

The sentence experiment is done for 12 times using common sentence according to the criteria tested, and 30 times using sentences taken from the Holy Qur'an.

Errors happen because the detection word is not added yet in the system and this can disturb the detection function in the following word. The result of experiment can be seen in Table 4 . 


\begin{tabular}{|c|c|c|c|}
\hline $\begin{array}{l}\text { Surah inAl- } \\
\text { Qur'an }\end{array}$ & Trial & Mistake & Arguments \\
\hline An- Nas: 4 & 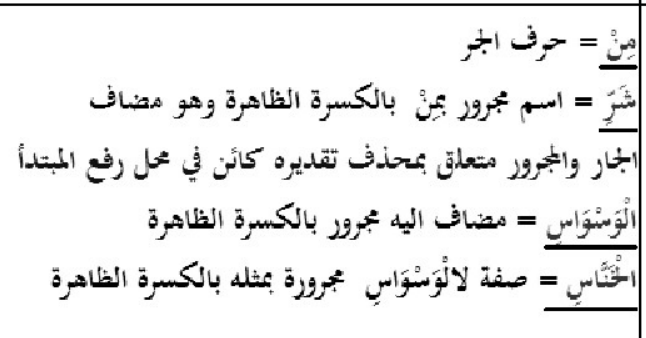 & $\begin{array}{l}\text { Are not } \\
\text { found }\end{array}$ & $\begin{array}{l}\text { الخناس become the } \\
\text { characters of } \\
\text { اللوسوسbecause } \\
\text { they are } \\
\text { isimma'rifah } \\
\text { having position as } \\
\text { majrur }\end{array}$ \\
\hline $\begin{array}{c}\text { Al- } \\
\text { 'Aadiyat:6 }\end{array}$ & 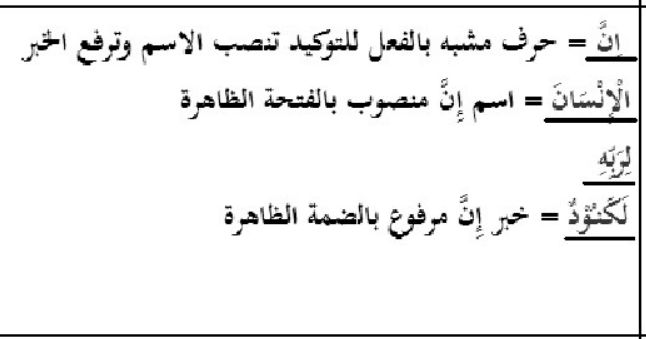 & $\begin{array}{c}\text { لربهnot } \\
\text { be detected }\end{array}$ & $\begin{array}{l}\text { Because there is } \\
\text { aharfjar } \\
\text { connecting to } \\
\text { isim. While } \\
\text { theharf is linked } \\
\text { yet error cannot } \\
\text { be detected } \\
\end{array}$ \\
\hline $\begin{array}{c}\text { Al- } \\
\text { 'Aadiyat:7 }\end{array}$ & 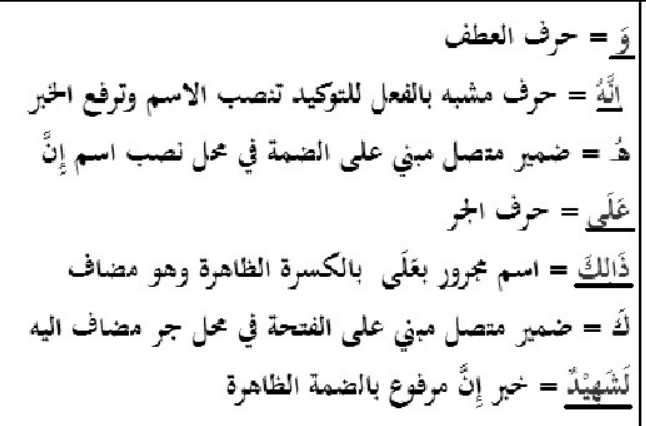 & $\begin{array}{c}\text { ذالل } \\
\text { detected as } \\
\text { isimmajrur } \\
\text { andmudhof }\end{array}$ & $\begin{array}{c}\text { Because ذالك is } \\
\text { not added yet to } \\
\text { the system, the } \\
\text { system searches } \\
\text { its own system in } \\
\text { different } \\
\text { condition. }\end{array}$ \\
\hline $\begin{array}{c}\text { Al- } \\
\text { Kautsar:1 }\end{array}$ & 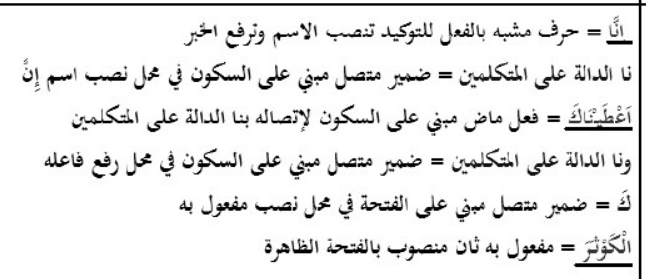 & $\begin{array}{c}\text { Errors } \\
\text { cannot be } \\
\text { found }\end{array}$ & $\begin{array}{l}\text { الكوثُز becomes } \\
\text { second maf'ulbih } \\
\text { because it has } \\
\text { been preceded by } \\
\text { maf'ulbih }\end{array}$ \\
\hline $\begin{array}{c}\text { Al- } \\
\text { Humazah:9 }\end{array}$ & 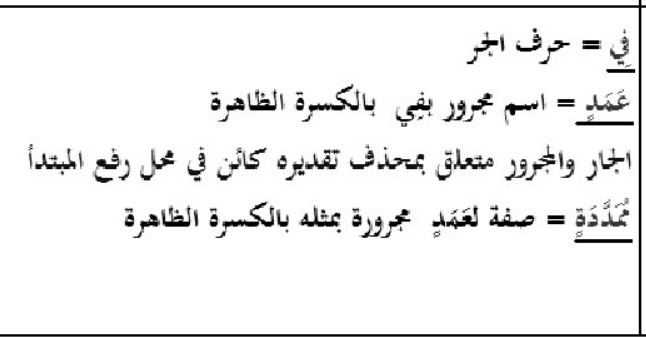 & $\begin{array}{c}\text { Errors } \\
\text { cannot be } \\
\text { found }\end{array}$ & $\begin{array}{c}\text { ممدادd etected as } \\
\text { character } \\
\text { of عمدaving } \\
\text { similar } \\
\text { condition that } \\
\text { isisimnakirahwit } \\
\text { h positionmajrur. }\end{array}$ \\
\hline
\end{tabular}




\begin{tabular}{|c|c|c|c|}
\hline An- Nashr:2 & 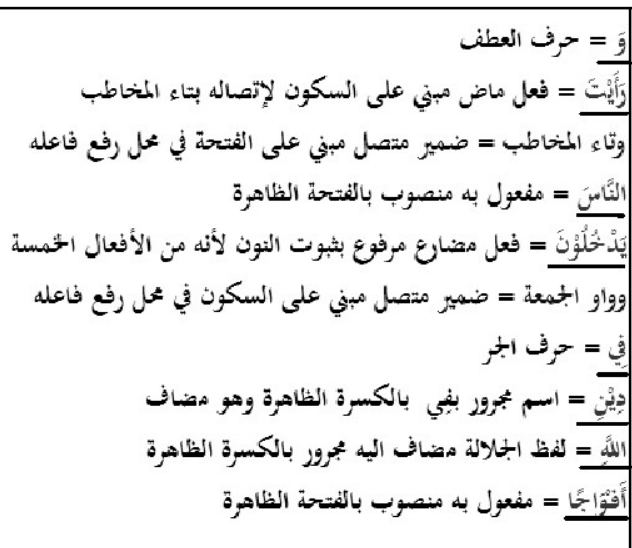 & $\begin{array}{c}\text { أفواجا } \\
\text { detected as } \\
\text { maf'ulbih }\end{array}$ & $\begin{array}{l}\text { The word should } \\
\text { become } \\
\text { haal(adjective). } \\
\text { Because the } \\
\text { condition that } \\
\text { determines the } \\
\text { haalis not } \\
\text { addedyet, the } \\
\text { word is detected as } \\
\text { an object. }\end{array}$ \\
\hline
\end{tabular}

\subsection{Work Evaluation by Users}

The questionnaires given to 5 persons, the users having teachers' profession at religious high school and Koranic school show the following responses:

1. The application is interesting because the users never see similar application. So the application is really new for the users.

2. The application is very complicated since the accuracy for storing the letters and the vowels is not easy. When harakat(vowel) is not properly entered, the result is not maximal. And when the harakat is not entered as the input, the system cannot make detection to the word.

3. As a whole the application is correct. When an error happens, it is caused by the system that is not added with suitable input or caused by the word which has similar word order and similar harakat with another word.

4. The application, as a whole, does not help much because the focus is on desktop. The user who does not have a desktop will never use the application.

5. From the perspective of users, the application should be used by students under the guidance of their teachers, so they can get assistance to learn the Arabic grammar.

\section{CONCLUSION}

Based on the survey, some conclusions can be proposed as follows:

1. Arabic grammar, especially nahwu, is really needed to comprehend the Holy Qur'an that is completely written in Arabic.

2. There are so many kinds of word and sentence forms which make the learners difficult to learn the nahwu knowledge.

3. This research employs NLP and expert systems to determine the word position in a sentence. 
4. The expert system employs knowledge base to determine the types of word and the inference engine is used to determine the function and position of word in a sentence.

5. When determining, the system involves 82 templates for every letter and harakat. The templates are then divided into 34 templates for verb, 34 for subject pronouns, and 14 object pronoun or possessive.

6. The output from this system is an i'rab (description of word function in sentence) that is written in Arabic language.

7. From the experiment, some conclusions are drawn as follows:

a. To detect the parts of speech from 117 experiments, the error happens because the condition of word that is equally the same with the other word.

b. To detect the word function in sentence, 42 experiments are done. The error happens because the system is not supplied with the word relatives yet. This makes the following word function detection in trouble.

8. From the questionnaires given to 5 persons, the users having profession as religious high school and Kuranic school teachers, it is concluded that the application needs more features to complete and improve the detection result. Besides the application is good when it is intended to help high school students, who still need the guidance from their teacher. The application can help them to study the grammar of Arabic language.

\section{REFERENCES}

[1] H. M. Harmain, H. El Khatib, A, Lakas, Arabic Text Mining, IADIS International Conference Applied Computing, 2004.

[2] M. Elkourdi, A.Bensaid, T. Rachidi, Automatic Arabic Document Categorization Based on the Naïve Bayes Algorithm, School of Science \& Engineering Alakhawayn University, 2004.

[3] M. A. El Halees, Arabic Text Classification Using Maximum Entropy, The Islamic University Journal, Vol. 15, No.1, pp. 157-167, 2007.

[4] Khairul Umam, Abu Abdin Nafi', Terjemahan Matan al Ajrumiyah, Sinar Baru Algensindo, Bandung, 2010.

[5] Ali Ridho Barakbah, Natural Language Processing, Lecture Notes, Departments of Information and Computer Engineering, Eelctronic Engineering Polytechnic Institute of Surabaya.

[6] Ali RidhoBarakbah, Expert System, Lecture Notes, Departments ofInformation and Computer Engineering, Eelctronic Engineering Polytechnic Institute of Surabaya. 